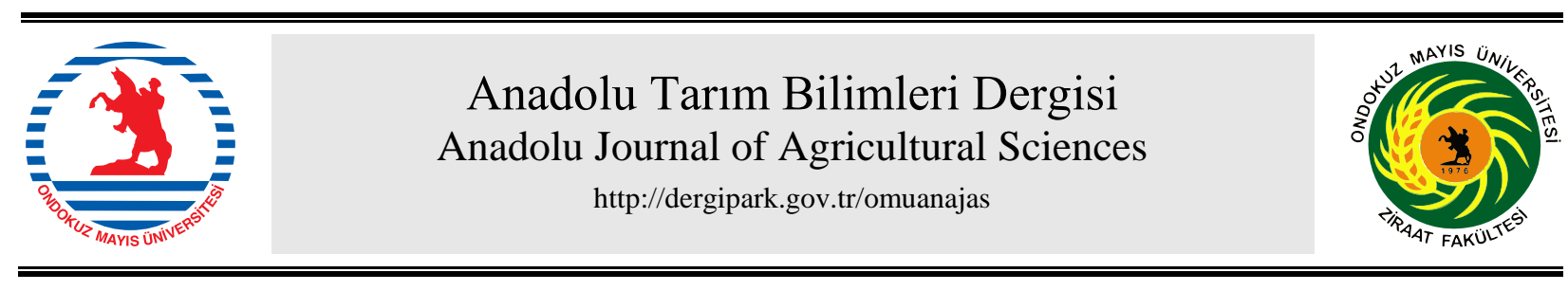

Araştırma/Research

Anadolu Tarım Bilim. Derg./Anadolu J Agr Sci, 32 (2017)

ISSN: 1308-8750 (Print) 1308-8769 (Online)

doi: 10.7161/omuanajas.290191

\title{
Bursa'da plum pox virus (Şarka)'ün yaygınlığının ve genetik çeşitliliğinin belirlenmesi
}

\author{
Kahraman GÜRCAN \\ Erciyes Üniversitesi, Ziraat Fakültesi, Tarımsal Biyoteknoloji Bölümü, Kayseri, Turkey \\ Sorumlu yazar/corresponding author:kgurcan@erciyes.edu.tr
}

Geliş/Received 21/01/2016 Kabul/Accepted 15/03/2016

\section{ÖZET}

Plum pox virus (PPV) tarafından oluşturulan Şarka hastalı̆̆ı, sert çekirdekli meyve türlerinin en önemli viral hastalığı olarak görülmektedir. Son yıllarda yapılan nükleotid dizileme çalışmaları ile PPV'nin Türkiye'de şehir merkezi ev bahçelerinde sanıldığından daha fazla yaygınlık ve genetik çeşitlilik gösterdiği belirlenmiştir. Ev bahçeleri Türkiye tipi PPV-D ve PPV-T ırkları ile bulaşı iken, kapama bahçeler Avrupa tipi PPV-M ırkı ile bulaşıktır. Bursa ili Türkiye'de önemli bir şeftali ve fidan üretim bölgesi olup, aynı zamanda Avrupa'dan gelen fidanların Türkiye içinde dağıtım merkezidir. Bu nedenle iyi izlenmesi gereken bir ildir. Bu çalışmada, Bursa ilinde surveyler yapılmış, tespit edilen PPV-pozitif örneklere ait izolatlar, Türkiye'nin diğer bölgelerinde ve Avrupa'da PPV izolatları ile karşılaştırılmıştır. Bursa ili ve civarında, 50 kapama bahçeden 118 örnek DASI-ELISA ve RT-PCR yöntemleri ile test edilmiş, 32 bahçeden alınan 64 örnek pozitif bulunmuştur. Bu örneklerin 664 nt uzunluğunda P3-6K1 bölgesi ve 969 nt uzunluğunda CT-3'UTR bölgesi dizilenmiş, GenBank'a kayıtll 200 adet izolat ile birlikte analiz edilmiştir. Otuz şeftali bahçesinden alınan 56 izolatın, Türkiye kapama bahçelerinde tespit edilen Avrupa PPV-M izolatı olduğu belirlenmiştir. Bursa'da iki erik bahçesinden alınan 8 adet izolat ise PPV-D olarak tespit edilmiş olup, bu izolatlar Türkiye tipi PPV-D izolatları ile aynı grupta yer almıştır. Sonuç itibariyle, Bursa kapama şeftali bahçelerinin Avrupa tipi PPV-M ile yaygın olarak bulaşık olduğu ve bu izolatların PPV'nin yeni giriş yaptığı Aydın, Denizli, Çanakkale, Isparta ve Kayseri illeri kapama bahçe izolatları ile yakın genetik benzerlik gösterdiği belirlenmiştir. Bu sonuç, PPV-M ırkının Türkiye'de yayılmasında, Bursa-Türkiye üzerinden olan fidan trafiğinin rolüne işaret etmiştir.

Determination of prevalence and genetic diversity of plum pox virus (sharka) in peach orchards in Bursa

\section{ABSTRACT}

Plum pox virus (PPV) is the most important viral disease of stone fruit species. Recent nucleotide sequencing studies have revealed that PPV is prevalent and exhibits high genetic diversity in residential gardens of several provinces in Turkey. Trees in residential gardens have been found to be infected by Turkish type PPV-D and PPV-T while trees in professional orchards in several cities have been found to be affected by the European strain PPV-M. The province Bursa is main peach producer region in Turkey but moreover Bursa hosts big nursery industry and is the distribution center of seedlings imported from European countries. In this research, surveys were made in the orchards of Bursa and surrounding regions, and comparisons were made in order to investigate genetic relationships among the isolates of Bursa and other PPV isolates determined in Turkey as well as European PPV isolates. A total of 118 samples from 50 orchards were examined by DASI-ELISA and RT-PCR methods. Of the all, 64 samples from 32 orchards were found to be infected with PPV. The P3-6K1 gene region with $664 \mathrm{nt}$ length and the CP-3'UTR with $970 \mathrm{nt}$ of the 64 isolates were sequenced and analyzed along with 200 sequence records in the GenBank database. Fifty-six isolates were identified as European type PPV-M. Eighth isolates from two plums orchard in Bursa were identified as PPV-D and grouped with Turkish type PPV-D. These results indicate that Bursa-Turkey seedlings traffic pathway seems to be the source of PPV-M infection in the orchards in the country.

Anahtar Sözcükler: Şarka Şeftali Sert Çekirdekli meyveler PPV-Marcus PPV-Dideron Keywords: Sharka Peach Stone fruits PPV-Marcus PPV-Dideron 


\section{Giriş}

Plum pox virus (PPV) sert çekirdekli meyvelerin en önemli viral etmeni olarak kabul edilmekte olup (Cambra ve ark., 2006), moleküler bitki patolojisinde en çok çalışılan 10 bitki virüsü arasında yer almaktadır (Scholthof ve ark., 2011). PPV, şu anda bilinen bitki virüslerinin yaklaşık \% 30'unu kapsayan Potyvirus cinsinin bir üyesidir. PPV sert çekirdekli meyve ağaçları için öldürücü değildir, fakat olgunlaşmadan meyve dökümüne neden olur, verimi düşürür ve meyve pazar değerini yok eder. Hastalığın belirtileri olarak klorotik lekeler, yaprak veya meyve halkaları, yapraklarda bükülme, meyvelerde koflaşma, şş̧kinlikler, renk açılmaları, kayısı çekirdeklerinde halkalı lekeler, şeftali çiçeklerinde renk açılmaları sayılabilir. Enfeksiyon bir kez başladıktan sonra, virüsün sert çekirdekli meyve üreten bölgelerde kontrolü oldukça zordur (Cambra ve ark., 2006).

PPV'nin sekiz ırkı tanımlanmıştır: C (Chery), $\mathrm{Cr}$ (Cherry Russia), D (Dideron), M (Marcus), EA (El Amar), Rec (Recombinant), T (Turkey) ve W (Winona) (García ve ark., 2014). Son olarak An (Ancestor Marcus), yeni bir urk olarak önerilmiștir (Palmisano ve ark., 2012; García ve ark., 2014). PPV-D ve PPV-M epidemiyolojik olarak ilk tanımlanan (Kerlan ve Dunez, 1979) iki yaygın gruptur. PPV-M, Güney, Doğu ve Orta Avrupa'da oldukça yaygındır (Myrta ve ark., 2001). PPV-M ilk olarak Yunanistan'da şeftaliden izole edilmiştir. Şeftalide yaygın olduğu gibi kayısı ve erik ağaçları da yaygın konukçusudur. Bir çok ülkede PPVD ırkı rapor edilmiştir (James ve ark., 2013). PPV-D, Avrupa'dan sonra Kuzey Amerika (Levy ve ark., 2000), Güney Amerika (Roy ve Smith, 1994) ve Japonya'da (Maejima ve ark., 2011) rapor edilmiştir. PPV-Rec, PPV-D ve M'den sonra en yaygin irk olup, Orta ve Doğu Avrupa'da yayılmış (Glasa ve ark., 2004); Türkiye'de (Candresse ve ark., 2007; Gürcan ve Ceylan, 2016b) ve Kanada'da (Thompson ve ark., 2001) tespit edilmiştir. PPV-An Arnavutluk'ta (Palmisano ve ark., 2012); PPV-C, Moldova'da (Kalashyan ve ark., 1994) ve Güney İtalya'da (Crescenzi ve ark., 1997); PPV-CR, Rusya'da (Glasa ve ark., 2013); PPV-EA, Misir'da kayıs1 ağaçlarında (Wetzel ve ark., 1991) rapor edilmiştir. PPV-T, Türkiye (Ulubaş Serçe ve ark., 2009); PPV-W, Kanada (James ve ark., 2003) ve Avrupa'da (Glasa ve ark., 2011) rapor edilmiştir.

Türkiye'de PPV ilk olarak yaklaşık yarım yüzyıl önce Edirne'de erikte tespit edilmiştir (Şahtiyancı, 1969; Kurçman, 1973). Sonraki yıllarda, Adana, Aydın, Ankara, Antalya, Aksaray, Edirne, Balıkesir, Bilecik, Bursa, Çanakkale, Denizli, Eskişehir, Kayseri, Kırklareli, Konya, İstanbul, İzmir, İzmit, Manisa, Mersin, Sakarya, Samsun, Tekirdağ ve Yalova illerinde (Akbaş ve ark., 2011; Candresse ve ark., 2007; Ceylan ve ark., 2014; Çelik ve Topkaya Kütük 2013; Çıtır ve İlbağı, 2008; Deligöz ve ark., 2015; Elibüyük 2004; Gümüş ve ark., 2007; Gürcan ve ark., 2016; Gürcan ve
Ceylan, 2016b; İlbağı ve Çıtır, 2014; İlbağı ve ark., 2008; İlbağı ve Çıtır, 2014; Koç ve Baloğlu, 2006; Ulubaş Serçe ve ark., 2011) PPV tespit edilmiştir. Türkiye'de PPV birçok kez rapor edilmesine rağmen, genelde serolojik test kullanılması, irk belirlemeye yönelik antikorların piyasada yeterince bulunmaması ve dizi analizi çalışmalarının son yıllara kadar mümkün olmaması gibi nedenlerden dolayı birçok bölgede PPV 1rk1 ve genetik varyasyonları rapor edilememiştir. Son yıllarda yapılan nükleotid dizileme çalışmaları, Türkiye'de PPV-D, M ve T irklarının yaygın olduğunu göstermiştir. Nükleotid dizilemeye dayalı olarak PPV-M izolatı, Bursa, Aydın, Çanakkale, Denizli, Isparta ve Kayseri (Gürcan ve Ceylan, 2016b) illeri kapama bahçelerinde saptanmıştır. $\mathrm{Bu}$ illerde bulunan $\mathrm{M}$ izolatlarının filogenetik ağaçta Avrupa M izolatları ile birlikte grup oluşturduğu görülmüştür. Aynı zamanda, Türkiye'ye özgün bir PPV-M gurubu ise, sadece İstanbul'da bulunmuştur (Gürcan ve ark, 2016). Türkiye'ye özgün İstanbul-M ırkının 10 izolatının tüm genomu dizilenmiştir (Teber ve Gürcan, 2016). Dizilemeye dayalı olarak PPV-D ırkı Türkiye'de; Aksaray/Ortaköy ve yakın köylerinde, Ankara, Bursa, Eskişehir, İstanbul, Konya ve Tekirdağ illerinde rapor edilmiştir (Gürcan ve Ceylan, 2016b). D izolatlarının 6 âdetinin tüm genomu dizilenmiş, filogenetik ağaçta Türkiye PPV-D izolatlarının bir grup, dünyanın geri kalan ülkelerinin izolatlarının ise, ayrı bir grup oluşturduğu görülmüsştür. Sonuçlar, Türkiye D izolatlarının Avrupa D izolatlarından farklı bir evrim tarihine sahip olabileceğine işaret etmiştir (Gürcan ve Ceylan, 2016a). Türkiye dışında sadece Arnavutluk'ta rapor edilen (Palmisano ve ark., 2015) PPV-T rrk1, Türkiye'de Ankara, İzmir, İstanbul, Kayseri, Konya, Tekirdağ ve Samsun illerinde tespit edilmiştir (Ulubaş Serçe ve ark., 2009; Ulubaş Serçe ve ark., 2011; İlbağ ve Çıtır, 2014; Deligöz ve ark., 2015, Gürcan ve Ceylan, 2016b). ). Son yillarda, Türkiye T izolatlarının 15 adetinin tüm genomu dizilenmiştir (Ulubaş Serçe ve ark., 2009; Ceylan ve ark., 2015). PPV-Rec ise, Isparta (Candresse ve ark., 2007) ve Bursa'da (Gürcan ve Ceylan, 2016b) rapor edilmiştir.

Türkiye'de önemli bir şeftali üretim bölgesi olan Bursa, aynı zamanda oldukça önemli bir fidan üretim yeri ve Avrupa'dan gelen fidanların Türkiye içinde dağıtım merkezilerinden biridir. Bursa ili, Türkiye fidan trafiğinde ve dolayısıyla bitkisel materyal ile taşınan meyve hastalıklarının Türkiye içinde yayılmasında önemli potansiyele sahiptir. Bursa'da PPV'nin mevcut olduğu 2011 ve 2016 yıllarında yayınlanan çalışmalarla belirlenmiştir. (Akbaş ve ark., 2011; Gürcan ve Ceylan, 2016b). Bu çalı̧̧mada farklı şehirlerde kapama bahçelerde hastalık yapan PPV izolatları ile Bursa izolatları arasındaki moleküler benzerlik araştırılmış, böylece PPV'nin kapama bahçelere bulaşma rotası belirlenmeye çalışılmıştır. 


\section{Materyal ve Yöntem}

\subsection{Survey}

Bursa ili ve civarında kapama sert çekirdekli meyve bahçeleri, 2015 ve 2016 Mayıs aylarında PPV belirtileri bakımından incelenmiştir. $\mathrm{Bu}$ amaç doğrultusunda 50 bahçede surveyler yapılmış ve PPV'nin yapraklarda tipik belirtileri, sarıdan açık yeşile değişen halka ve lekeler, çizgi ve bantlar; meyvede deformasyon, halka ve şişkinlik simptomları araştırılmıştır. Survey yapılan bölgenin Google Earth görüntüsü Şekil 1'de verilmiştir.

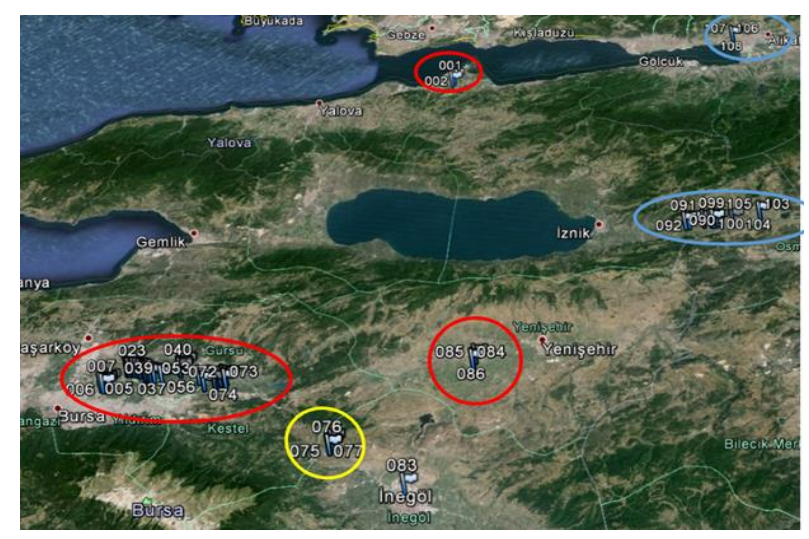

Şekil 1. Örneklerin alındığı bölgeleri gösteren Google Earth görüntüsü

Şekil 1. de kırmızı daire içine alınan üç bölge PPV$M$ ile bulaşık alanları göstermektedir. Sarı daire PPV-D ile bulaşık örneklerin toplandığı, mavi ise örneklerin negatif çıktığ1 iki bölgeyi göstermektedir. GPS rakamlarının yoğunluğu ile pozitif örnek yoğunluğu orantılı değildir. En çok örnek Bursa Merkez ve Gürsu civarındaki bahçelerden alınmıştır. Google Earth genişletilip bu bölge odaklandığında tüm örneklerin alındığı noktalar görülebilmektedir.

\subsection{Double Antibody Sandwich Indirect (DASI)-ELISA Testi}

Surveyler sırasında toplanan yaprak örnekleri araba tipi buzdolabı içinde Kayseri'ye getirilmiş ve laboratuvarda Avrupa ve Akdeniz Bitki Koruma Teşkilatı (European and Mediterranean Plant Protection Organization (EPPO) protokolüne göre 1 gr yaprak, 20 $\mathrm{ml}$ ekstraksiyon çözeltisi içinde homojenize edilmiştir (EPPO 2004). Ekstraksiyon çözeltisi, Phosphate buffer saline (PBS), \% 2 Polyvinylpyrrolidone (PVP-10) ve $\% \quad 0.2$ sodium diethyl dithiocarbamate (DIECA) karıştırılarak hazırlanmıştır. Homojenize edilmiş örnekler $-20{ }^{\circ} \mathrm{C}$ 'de muhafaza edilmiştir. DASI-ELISA, PPV'ye özgü antikor 5B-IVIA kullanılarak yapılmıştır. DASI-ELISA kitleri, Real, (Valencia, İspanya) şirketinden satın alınmış ve testler, üretici firmanın talimatlarına ve EPPO protokolü (2004)'ne göre yapılmıştır. Testler 96 kuyuluk ELISA pleytlerinde yapılmış ve her örnek için ikişer kuyu kullanılmıştır. Her ELISA pleytinde negatif, pozitif ve tampon kontrol bulunmuş ve okumalar, PowerWave 200 (BioTek Instruments, Winooski, VT, USA) spektrofotometrede $405 \mathrm{~nm}$ dalga boyunda, 30, 60 ve 90'1nc1 dakikalarda olmak üzere üçer kez yapılmıştır. Negatif kontrolün en az 2 katı ve üzeri optik yoğunluğa (optical density; OD) sahip örnekler pozitif olarak kabul edilmiştir.

\section{3. $R T-P C R$}

Homojenize örneklerden alınan $300 \mu \mathrm{l}$ ekstrakt RNA izolasyonu için kullanılmıştır. Total RNA'lar Geneaid marka ticari kit (Geneaid Biotech Ltd, Taiwan) kullanılarak izole edilmiştir. RNA miktarı NanoDrop 2000 (Thermo Fisher Scientific Inc., Waltham, MA. ABD) kullanılarak ölçülmüştür. cDNA'lar Moloney Murine Leukemia Virus (M-MLV) ters transkriptaz (Invitrogen, ON, Kanada) kullanarak üretici firmanın protokolü modifiye edilerek elde edilmiştir. Özetle, $1 \mu 1$ $70 \mu \mathrm{M}$ Oligo(dT)23 ve $1 \mu 110 \mathrm{mM}$ dNTP, $10 \mu \mathrm{l}$ RNA (ortalama $30 \mathrm{ng} / \mathrm{ml}$ RNA) ile karıştırılıp, 5 dakika $65^{\circ} \mathrm{C}$ 'de tutulmuş, daha sonra buzun üzerinde soğutulmuştur. Üzerine karışım B [4 $\mu 1$ 5X First-Strand Buffer, $2 \mu \mathrm{l} 0.1 \mathrm{M}$ DTT ve $1 \mu \mathrm{l}$ (200 U) M-MLV] eklenmiş ve $37{ }^{\circ} \mathrm{C}$ 'de $50 \mathrm{dk}, 70{ }^{\circ} \mathrm{C}$ 'de $15 \mathrm{dk}$ tutulmuştur. PPV'ye özgün iki primer çifti kullanılarak PCR yöntemiyle cDNA çoğaltılmıştır. Birinci primer çifti PPV genomunda 2915 ve 3750 nt arasındaki 835 nükleotidlik bölgeyi çoğaltmakta olup (Numaralandırma GenBank AJ243957 numaralı izolata göre yapılmıştır), P3 genin 3' bölgesini (580 nt), 6K1 geninin tamamını (156 nt) ve CI geninin $100 \mathrm{nt}$ 5' bölgesini içermektedir. $\mathrm{Bu}$ bölge için 5' primer PP3 ve 3' primer PCI primer dizisi Glasa ve ark., (2002) tarafından geliştirilmiştir. İkinci bölge olarak ise PPV Genomunda 8727-9784 nt aras1 (Numaralandırma GenBank emb|HF585104.1 numaralı izolata göre yapılmıştır) çoğaltılmıştır. Bu bölge PPV genomunun 3' kilıf proteini (842nt) bölgesini ve 3' UTR (215 nt)'sini içermektedir. Bu bölge için 5 , primer (5' CCAGCAACAACTCAGCCTGC-3') ve 3' primer (5' CTCTTGCACAAGAACTAT-3') Primer3 programı kullanılarak geliştirilmiştir.

PCR karışımı $25 \mu$ l toplam hacimde: $2.5 \mu \mathrm{l} 10 \mathrm{X}$ Taq Buffer, $25 \mathrm{mM} \mathrm{MgCl}_{2}, 5 \mathrm{mM}$ dNTP $0.5 \mu \mathrm{l}$ Taq polimeraz (5 U), $25 \mu \mathrm{M} 5$ ' primer, $25 \mu \mathrm{M} 3$ ' primer ve $2.5 \mu \mathrm{l}$ cDNA içerecek şekilde hazırlanmış ve Thermal Cycler cihazında (T100 Termal Cycler (Bio-Rad Laboratories, Hercules, CA, ABD) çoğaltım gerçekleştirilmiştir. PCR programı $94{ }^{\circ} \mathrm{C}$ 'de $3 \mathrm{dk}$ ve 35 döngü $94{ }^{\circ} \mathrm{C}$ 'de $30 \mathrm{sn}, 60{ }^{\circ} \mathrm{C}$ 'de $1 \mathrm{dk}, 72{ }^{\circ} \mathrm{C}$ 'de $1,5 \mathrm{dk}$ ile son olarak $72{ }^{\circ} \mathrm{C}$ 'de $15 \mathrm{dk}$ son uzama olacak şekilde ayarlanmıştır. PCR ürünlerinden 7'şer $\mu \mathrm{l}$ 'si $0.5 \mu \mathrm{g} / \mathrm{ml}$ oranında ethidium bromid içeren \% 2'lik agaroz jele yüklenmiş ve $1 \mathrm{X}$ TBE tamponu içinde $100 \mathrm{~V}$ ' ta 3 saat süre ile yürütülmüştür. Sonuçlar, DNA görüntüleme cihazında UV 1 şı altında gerçekleştirilmiştir. Kalan PCR ürünleri nükleotid dizileme çalışması için 
kullanılıncaya kadar $-20^{\circ} \mathrm{C}$ 'de muhafaza edilmiştir.

\subsection{Dizi analizi}

PCR ürünleri önce ExoSap uygulanarak temizlenmiştir. Bunun için Exonuclease I'den 0,5 $\mu \mathrm{l}$ ve Shrimp Alkaline Phosphatase enziminden $1 \mu 1,5 \mu 1$ PCR ürünü ile karıștırılıp $37^{\circ} \mathrm{C}$ 'de $30 \mathrm{dk}$ ve $80^{\circ} \mathrm{C}$ 'de 15 dakika inkube edilmiştir. Parçaların dizinlenmesinde BigDye Terminator v1.1 Cycle Sequencing kiti (Applied Biosystems, Foster City, CA, ABD) kullanılmıştır. Nanodrop (NanoDrop Technologies, Wilmington, DE) ile konsantrasyonu belirlenen bir önceki aşamanın ürününden $8 \mathrm{ng}$ alınmış, $2 \mu \mathrm{l}$ BigDye reaksiyon karışımı, $2 \mu 1$ Sequencing Buffer ve $1.2 \mathrm{pM}$ primer eklenmiş, saf su ile $10 \mu l^{\prime}$ ye tamamlanmıştır. PCR döngüsü olarak $95{ }^{\circ} \mathrm{C}$ 'de $1 \mathrm{dk}$ tutulmuş ve 35 döngü çoğaltım aşaması $\left(95^{\circ} \mathrm{C}^{\prime} \mathrm{de} 1 \mathrm{dk}, 50^{\circ} \mathrm{C}^{\prime} \mathrm{de} 15 \mathrm{sn}\right.$, $60{ }^{\circ} \mathrm{C}$ 'de $4 \mathrm{dk}$ ) gerçekleştirilmiştir. Sekans PCR'ından çıkan ürün ve BigDye Xterminator saflaştırma kiti
(Applied Biosystems) kullanılarak temizlenmiştir. Bunun için $40 \mu \mathrm{l} \mathrm{SAM} \mathrm{solüsyonu} \mathrm{ve} 10$ XTerminator solüsyonu ile karıştırılıp $30 \mathrm{dk} 2200 \mathrm{rpm}$ 'de tutulmuş ve sonra 1000 rpm'de 2 dakika çöktürüldükten sonra $A B I$ 3500 DNA Analiz (Applied Biosystems) cihazına yüklenmiştir. DNA dizileri öncelikle BioEdit (http://www.mbio.ncsu.edu/bioedit/bioedit.html)

programı kullanılarak görselleştirilmiş ve hatalı üretilen diziler çalışmadan çıkarılmıştır. Bu çalışmada 64 izolattan 116 parça dizi elde edilmiş ve diziler GenBank'a kaydedilmiştir (Çizelge 1). İzolatların isimlendirilmesinde önce şehir ismi kısaltması, sonra meyve türü kısaltması, daha sonra ise GPS numarası kullanılmıştır. Örneğin $\mathrm{BrPc} 10$ isimli izolatta $\mathrm{Br}=$ Bursa, Pc $=$ Şeftali $($ Peach), ve $10=$ GPS numarasını göstermektedir (Çizelge 2). Referans olarak ilk başta GenBank'ta bulunan tüm izolatlara ait $\mathrm{P} 3-6 \mathrm{~K} 1$ veya $\mathrm{CP}$ 3'UTR bölgeleri indirilmiş ve filogenetik ağaç oluşturulmuştur.

Çizelge 1. Örnek bilgileri ve GenBank kayıt numaraları

\begin{tabular}{cccccc}
\hline & & & & \multicolumn{2}{c}{ GenBank Kayıt No } \\
\hline Bahçe No. & Tür & Yer & Strain & P3-6K1 & Kılıf+3'UTR \\
\hline 1,4 & Şeftali & Yalova/Subaş1 & M & KX423842-846 & KX423897-901 \\
6 & Şeftali & Bursa/Samanlı & M & KX423847-850 & KX423902-905 \\
$10,12,13,14,15,16$ & Şeftali & Bursa/Kumlukalanı & M & KX423851-858 & KX423906-915 \\
$17,18,19,20$ & Şeftali & Bursa/Gürsu & M & KX423859-862 & KX423916-920 \\
$21,22,23,24,25$ & Şeftali & Bursa/Hasanköy & M & KX423863-869 & KX423921-930 \\
26,27 & Şeftali & Bursa/Adaköy & M & KX423870-872 & KX423931-935 \\
$28,29,31,32,33,34$ & Şeftali & Bursa/Serme & M & KX423873-881 & KX423936-944 \\
35,36 & Erik & Bursa/Şehitler & D & KX423882-889 & KX423945-952 \\
39 & Şeftali & Bursa/Çeltikli & M & & - \\
40 & Şeftali & Bursa/Yolören & M & KX423890 & KX423953 \\
49,50 & Şeftali & Bursa & M & KX423891-896 & KX423955-957 \\
\hline
\end{tabular}

Fakat özellikle PPV-D ve PPV-M ırkları için CP-3' UTR bölgesi; PPV-T rrk için ise P3-6K1 bölgesi fazla olduğunda, GenBank örnek sayısı azaltılarak tekrar filogenetik ağaç kurulmuştur. Örnek sayısı azaltılırken PPV'de genetik çeşitliliğ̆i temsil edecek, filogenetik ağaç üzerinde mesafeli dağılmış, farklı ülkelerden izolatların seçilmesine dikkat edilmiştir. PPV-an, PPVC, PPV-CR, PPV-EA, PPV-Rec, PPV-W irklarından ise, bulunan tüm örnekler alınmıştır. Son kertede bu çalışma kapsamında sunulan filogenetik ağaçlarda 199 adet PPV izolatının kayıtlı P3-6K1 veya CP-3'UTR Bursa dizileri ile birlikte çalışılmıştır. GenBank izolatlarının kayıt numaraları Çizelge 2.' de verilmiştir. GenBank İzolatlarından 100 adeti daha önce Türkiye'den rapor edilenler olup, bunların 37 adeti Türkiye' D izolatı, 25 adeti Avrupa PPV-M izolatı, 21 adeti İstanbul-M izolatı, ve 17 adeti PPV-T izolatıdır. Geriye kalan 99 örnek ise farklı ülkelerden rapor edilen
GenBank'a kaydedilmiș izolatlardır. Tüm diziler öncelikle BioEdit (http://www.ebi.ac.uk/ Tools/msa/clustalw2/) program1 kullanılarak eşleştirilmiş, 664 bazlık konsensuslar üretilmiştir. Konsensus parçalar Mega 6 (Tamura ve ark., 2013) 1000 Bootstrap değeri seçilerek Neighbour-joining (NJ) filogenetik ağacı elde edilmiştir. Maximum Likelihood, Minimum Evolution, UPGMA ve Maximum Parsimony ağaçları da üretilmiş, fakat Neighbour-joining ağacından farklı bir ağaç elde edilmediği için Neighbour-joining filogenetik ağacı görüntüsü esas alınmıştır. Gruplar aras1 tahmini evrimsel benzerlik ve rraksaklık (Estimates of average evolutionary similarity and divergence) ve grup için genetik varyasyon değerleri (the intragroup genetic variability) Maximum Composite Likelihood modeli (Tamura ve ark., 2004) kullanılarak Mega 6 programında hesaplanmıştır. 
Çizelge 2. Filogenetik Analizlerde Kullanılan GenBank İzolatları

\begin{tabular}{|c|c|c|c|c|c|}
\hline \multirow[b]{2}{*}{ İzolat } & \multirow[b]{2}{*}{ Şehir/Ülke } & \multirow[b]{2}{*}{ Irk } & \multirow[b]{2}{*}{ Konukcu* } & \multicolumn{2}{|c|}{ GenBank No } \\
\hline & & & & P3-6K1 & $\mathrm{CP}+3$ 'UTR \\
\hline AL11pl & Arnavutluk & An & P. domestica & HF674399 & HF674399 \\
\hline BY101 & Belarus & $\mathrm{C}$ & P. hybrid cultivar L2 & HQ840517 & HQ840517 \\
\hline BY181 & Belarus & $\mathrm{C}$ & P. hybrid cultivar OWP-6 & HQ840518 & HQ840518 \\
\hline SoC & Buğdan & $\mathrm{C}$ & - & AY 184478 & AY184478 \\
\hline $\mathrm{SwC}$ & İtalya & $\mathrm{C}$ & - & Y09851 & Y09851 \\
\hline Volk143 & Rusya & $\mathrm{C}$ & P. cerasus & - & KJ787006 \\
\hline $\mathrm{RU}-17 \mathrm{sc}$ & Rusya & $\mathrm{CR}$ & Vişne & КC020124 & KC020124 \\
\hline RU-18sc & Rusya & $\mathrm{CR}$ & Vişne & КC020125 & KC020125 \\
\hline RU-30sc & Rusya & $\mathrm{CR}$ & Vişne & КC020126 & KC020126 \\
\hline 92011 & Fransa & $\mathrm{D}$ & - & AF357545 & - \\
\hline 93080 & Fransa & $\mathrm{D}$ & - & AF357546 & - \\
\hline $48-922$ & Kanada & $\mathrm{D}$ & P. persica & - & AY912058 \\
\hline $48-922$ & Kanada & $\mathrm{D}$ & P. persica (Redhaven peach) & AY912058 & - \\
\hline Ak1 & Japonya & $\mathrm{D}$ & P. mume cv. Nanko & - & AB576045 \\
\hline Ak3 & Japonya & $\mathrm{D}$ & P. тите & AB576047 & - \\
\hline AkOrAp166 & Aksaray/Türkiye & $\mathrm{D}$ & Kayı1s1 & KM410026 & - \\
\hline AkOrAp187 & Aksaray/Türkiye & $\mathrm{D}$ & Kayıs1 & KM410029 & - \\
\hline AkOrPl284 & Aksaray/Türkiye & $\mathrm{D}$ & Erik & KM410027 & - \\
\hline AnCnAp14 & Ankara/Türkiye & $\mathrm{D}$ & Kay1s1 & KM409736 & - \\
\hline AnCnAp56 & Ankara/Türkiye & $\mathrm{D}$ & Kay1s1 & KM410040 & - \\
\hline AnCnAp57 & Ankara/Türkiye & $\mathrm{D}$ & Kayıs1 & KM410037 & - \\
\hline AnCnAp63 & Ankara/Türkiye & $\mathrm{D}$ & Kayı1s1 & KM410038 & - \\
\hline AnCnAp64 & Ankara/Türkiye & $\mathrm{D}$ & Kayısı & KM410039 & - \\
\hline AnCnPl10 & Ankara/Türkiye & $\mathrm{D}$ & Erik & KM409735 & - \\
\hline $\mathrm{BIII} / 2$ & Slovakya & $\mathrm{D}$ & P. domestica (plum) & - & GU461890 \\
\hline BrInP1241 & Bursa/Türkiye & $\mathrm{D}$ & Erik & KM410030 & - \\
\hline BrInPl243 & Bursa/Türkiye & $\mathrm{D}$ & Erik & KM410028 & - \\
\hline BrInP1244 & Bursa/Türkiye & $\mathrm{D}$ & Erik & KM410031 & - \\
\hline Ca123-1 & Kanada & $\mathrm{D}$ & P. persica & AY953267 & - \\
\hline $\mathrm{Ca} 3$ & Kanada & $\mathrm{D}$ & P. persica & AY953262 & - \\
\hline Cdn 12 & Kanada & $\mathrm{D}$ & P. domestica & - & AY953266 \\
\hline $\mathrm{Cdn} 4$ & Kanada & $\mathrm{D}$ & P. persica & - & AY953263 \\
\hline Cdn 5 & Kanada & $\mathrm{D}$ & P. persica & AY953264 & AY953264 \\
\hline Cdn1 & Kanada & $\mathrm{D}$ & P. domestica & AY953261 & AY953261 \\
\hline $\mathrm{Cdn} 7-2$ & Kanada & $\mathrm{D}$ & P. glandulosa & AY953265 & - \\
\hline $\mathrm{D}$ & Fransa & $\mathrm{D}$ & - & - & X16415 \\
\hline EsGrAp260 & Eskişehir/Türkiye & $\mathrm{D}$ & Kayısı & KM410033 & - \\
\hline EsMrAp258 & Eskișehir/Türkiye & $\mathrm{D}$ & Kayısı & KM410034 & - \\
\hline EsMrAp259 & Eskişehir/Türkiye & $\mathrm{D}$ & Kayısı & KM410041 & - \\
\hline Fantasia & Kanada & $\mathrm{D}$ & P. persica var. nectarina & - & AY912056 \\
\hline $\mathrm{Ha} 2$ & Japonya & $\mathrm{D}$ & P. mите & AB576049 & AB576049 \\
\hline $\mathrm{Ha} 3$ & Japonya & $\mathrm{D}$ & P. тите & AB576050 & - \\
\hline $\mathrm{Ha} 4$ & Japonya & $\mathrm{D}$ & P. тите & AB576051 & AB576051 \\
\hline $\mathrm{Hi} 2$ & Japonya & $\mathrm{D}$ & P. mume cv. Shirokaga & - & AB576053 \\
\hline IsUsAp219 & İstanbul/Türkiye & $\mathrm{D}$ & Kayıs1 & KM410032 & - \\
\hline isAp34 & İstanbul/Türkiye & $\mathrm{D}$ & Kayıs1 & KT230757 & KT827117 \\
\hline isAp95 & İstanbul/Türkiye & $\mathrm{D}$ & Kayı1s1 & KT230781 & - \\
\hline isP1150 & İst nbul/Türkiye & $\mathrm{D}$ & Erik & KT230806 & KT827161 \\
\hline isP1174 & İstanbul/Türkiye & $\mathrm{D}$ & Erik & KT230810 & KT827168 \\
\hline isP1192 & İstanbul/Türkiye & $\mathrm{D}$ & Erik & KT230816 & KT827174 \\
\hline isPl215 & İstanbul/Türkiye & $\mathrm{D}$ & Erik & KT230824 & KT827181 \\
\hline isP1237 & İstanbul/Türkiye & $\mathrm{D}$ & Erik & KT230828 & KT827184 \\
\hline isPl5 & İstanbul/ ürkiye & $\mathrm{D}$ & Erik & KT230749 & KT827109 \\
\hline KnAnP1152 & Konya/Türkiye & $\mathrm{D}$ & Erik & KM410036 & - \\
\hline
\end{tabular}


Çizelge 2 (Devamı). Filogenetik analizlerde kullanılan GenBank izolatları

\begin{tabular}{|c|c|c|c|c|c|}
\hline \multirow[b]{2}{*}{ İzolat } & \multirow[b]{2}{*}{ Şehir/Ülke } & \multirow[b]{2}{*}{ Irk } & \multirow[b]{2}{*}{ Konukçu* } & \multicolumn{2}{|c|}{ GenBank No } \\
\hline & & & & P3-6K1 & $\mathrm{CP}+3^{\prime} \mathrm{UTR}$ \\
\hline KnMrAp152 & Konya/Türkiye & $\mathrm{D}$ & Kayıs1 & KM410035 & - \\
\hline KnMrAp18 & Konya/Türkiye & $\mathrm{D}$ & Kay1s1 & KM409733 & - \\
\hline KnMrAp33 & Konya/Türkiye & $\mathrm{D}$ & Kay1s1 & KM409734 & - \\
\hline KnMrAp6 & Konya/Türkiye & $\mathrm{D}$ & Kay1s1 & KM409731 & - \\
\hline KnMvAp335 & Konya/Türkiye & $\mathrm{D}$ & Kay1s1 & KM410043 & - \\
\hline KnMvAp336 & Konya/Türkiye & $\mathrm{D}$ & Kay1s1 & KM410044 & - \\
\hline KnMvAp343 & Konya/Türkiye & $\mathrm{D}$ & Kayısı & KM410042 & - \\
\hline $\mathrm{Ok} 2$ & Japonya & $\mathrm{D}$ & P. тите & AB576057 & - \\
\hline Ou1 & Japonya & $\mathrm{D}$ & P. mume cv. Nanko & - & AB545926 \\
\hline Ou14 & Japonya & $\mathrm{D}$ & P. mume cv. Kurenai & - & AB576068 \\
\hline Ou16 & Japonya & $\mathrm{D}$ & P. mume & - & AB576070 \\
\hline Ou7 & Japonya & $\mathrm{D}$ & P. mume & AB576063 & - \\
\hline PENN2 & $\mathrm{ABD}$ & $\mathrm{D}$ & P. domestica & - & AF401296 \\
\hline Penn3 & $\mathrm{ABD}$ & $\mathrm{D}$ & Şeftali & - & DQ465242 \\
\hline Penn4 & $\mathrm{ABD}$ & $\mathrm{D}$ & - & EF611248 & - \\
\hline Penn4 & $\mathrm{ABD}$ & $\mathrm{D}$ & Şeftali & - & DQ465243 \\
\hline Penn7 & $\mathrm{ABD}$ & $\mathrm{D}$ & Şeftali & - & EF640935 \\
\hline Penn9 & $\mathrm{ABD}$ & $\mathrm{D}$ & Şeftali & - & EF640937 \\
\hline SK-272pe & Slovakya & $\mathrm{D}$ & P. persica & - & HF585098 \\
\hline TkCoAp16 & Tekirdağ/Türkiye & $\mathrm{D}$ & Kayı1s1 & KM409738 & - \\
\hline TkCoAp19 & Tekirdă̆/Türkiye & $\mathrm{D}$ & Kayı1s1 & KM409744 & - \\
\hline TkCoPl15 & Tekirdağ/Türkiye & $\mathrm{D}$ & Erik & KM409737 & - \\
\hline TkMtAp1 & Tekirdağ/Türkiye & $\mathrm{D}$ & Kayısı & KM409745 & - \\
\hline TkMtAp2 & Tekirdağ/Türkiye & $\mathrm{D}$ & Kayı1sı & KM409746 & - \\
\hline Vulcan & Kanada & $\mathrm{D}$ & P. persica & - & AY912057 \\
\hline ElAmar & - & EA & - & AM157175 & AM157175 \\
\hline ElAmar & Misir & EA & P. armeniaca & - & DQ431465 \\
\hline 91003 & - & $\mathrm{M}$ & - & AF357548 & - \\
\hline 91006 & - & $\mathrm{M}$ & - & AF357549 & - \\
\hline 94061 & - & M & - & AF357547 & - \\
\hline AyMcAp191 & Aydın/Türkiye & $\mathrm{M}$ & Kayı1s1 & KM409962 & - \\
\hline AyMcAp192 & Aydın/Türkiye & M & Kay1s1 & KM409963 & - \\
\hline AyYpAp199 & Aydın/Türkiye & M & Kay1s1 & KM409966 & - \\
\hline AyYpAp200 & Aydın/Türkiye & M & Kay1s1 & KM409967 & - \\
\hline AyYpAp201 & Aydın/Türkiye & M & Kay1s1 & KM409960 & - \\
\hline AyYpAp202 & Aydın/Türkiye & M & Kay1s1 & KM409964 & - \\
\hline AyYpAp203 & Aydın/Türkiye & M & Kay1s1 & KM409959 & - \\
\hline AyYpAp204 & Aydın/Türkiye & M & Kay1s1 & KM409961 & - \\
\hline BG1 & Bulgaristan & M & Erik & EF626559 & - \\
\hline BG2 & Bulgaristan & $\mathrm{M}$ & Şeftali & EF626560 & - \\
\hline BG3 & Bulgaristan & $\mathrm{M}$ & Şeftali & EF626561 & - \\
\hline BG4 & Bulgaristan & M & Şeftali & EF626562 & - \\
\hline BG5 & Bulgaristan & M & Şeftali & EF626563 & - \\
\hline BG6 & Bulgaristan & M & - & EF626564 & - \\
\hline CnK1Pc26 & Çanakkale/Türkiye & M & Şeftali & KM409952 & - \\
\hline CnK1Pc264 & Çanakkale/Türkiye & M & Şeftali & KM409954 & - \\
\hline CnKlPc265 & Çanakkale/Türkiye & M & Şeftali & KM409948 & - \\
\hline CnKlPc27 & Çanakkale/Türkiye & $\mathrm{M}$ & Şeftali & KM409953 & - \\
\hline CnKLPc28 & Çanakkale/Türkiye & M & Şeftali & KM409950 & - \\
\hline CY1 & Kibris & M & - & EF626584 & - \\
\hline CY2 & Kibris & $\mathrm{M}$ & - & EF626585 & - \\
\hline $\mathrm{CZ1}$ & Çek Cumhuriyeti & M & Kay1sı & EF626566 & - \\
\hline $\mathrm{CZ2}$ & Çek Cumhuriyeti & M & Şeftali & EF626565 & - \\
\hline DnKoAp189 & Denizli/Türkiye & M & Kayıs1 & KM409955 & - \\
\hline DnKoAp190 & Denizli/Türkiye & $\mathrm{M}$ & Kayıs1 & KM409956 & - \\
\hline
\end{tabular}


Çizelge 2 (Devamı). Filogenetik analizlerde kullanılan GenBank izolatları

\begin{tabular}{|c|c|c|c|c|c|}
\hline \multirow[b]{2}{*}{ İzolat } & \multirow[b]{2}{*}{ Şehir/Ülke } & \multirow[b]{2}{*}{ Irk } & \multirow[b]{2}{*}{ Konukçu* } & \multicolumn{2}{|c|}{ GenBank No } \\
\hline & & & & P3-6K1 & CP+3'UTR \\
\hline FR3 & Fransa & $\mathrm{M}$ & Şeftali & EF626568 & - \\
\hline FR4 & Fransa & $\mathrm{M}$ & Şeftali & EF626569 & - \\
\hline GR0019 & Yunanistan & $\mathrm{M}$ & - & FM955843 & FM955843 \\
\hline GR1 & Yunanistan & $\mathrm{M}$ & - & EF626580 & - \\
\hline GR2 & Yunanistan & $\mathrm{M}$ & - & EF626578 & - \\
\hline GR3 & Yunanistan & $\mathrm{M}$ & Kayıs1 & EF626579 & - \\
\hline IpMrPc168 & İstanbul/Türkiye & $\mathrm{M}$ & Seftali & KM409946 & - \\
\hline IpMrPc169 & Isparta/Türkiye & $\mathrm{M}$ & Şeftali & KM409951 & - \\
\hline IpMrPc170 & Isparta/Türkiye & $\mathrm{M}$ & Şeftali & KM409949 & - \\
\hline IpMrPc171 & Isparta/Türkiye & $\mathrm{M}$ & Şeftali & KM409968 & - \\
\hline IpMrPc40 & İstanbul/Türkiye & $\mathrm{M}$ & Şeftali & KM409947 & - \\
\hline IpMrPc42 & Isparta/Türkiye & $\mathrm{M}$ & Şeftali & KM409969 & - \\
\hline IsInAp246 & İstanbul/Türkiye & $\mathrm{M}$ & Kayısı & KM409957 & - \\
\hline IT1 & İtalya & $\mathrm{M}$ & Erik & EF626581 & - \\
\hline IT2 & İtalya & $\mathrm{M}$ & Erik & EF626582 & - \\
\hline IT3 & İtalya & $\mathrm{M}$ & Şeftali & EF626583 & - \\
\hline isAp140 & İstanbul/Türkiye & $\mathrm{M}$ & Kayısı & KT230800 & KT827155 \\
\hline isAp156 & İstanbul/Türkiye & $\mathrm{M}$ & Kayıs1 & KT230808 & KT827163 \\
\hline isAp165 & İstanbul/Türkiye & $\mathrm{M}$ & Kayıs1 & - & KT827165 \\
\hline isAp97 & İstanbul/Türkiye & $\mathrm{M}$ & Kayıs1 & - & KT827139 \\
\hline isPl109 & İstanbul/Türkiye & M & Erik & - & KT827144 \\
\hline isPl129 & İstanbul/Türkiye & M & Erik & KT230793 & - \\
\hline isP1130 & İstanbul/Türkiye & $\mathrm{M}$ & Erik & KT230794 & KT827150 \\
\hline isP1141 & İstanbul/Türkiye & $\mathrm{M}$ & Erik & KT230801 & - \\
\hline isPl152 & İstanbul/Türkiye & $\mathrm{M}$ & Erik & KT230807 & - \\
\hline isP1189 & İstanbul/Türkiye & $\mathrm{M}$ & Erik & KT230815 & - \\
\hline isP1195 & İstanbul/Türkiye & M & Erik & - & KT827175 \\
\hline isP1199 & İstanbul/Türkiye & M & Erik & KT230818 & KT827176 \\
\hline isPl2 & İstanbul/Türkiye & $\mathrm{M}$ & Erik & KT230748 & KT827108 \\
\hline isPl201 & İstanbul/Türkiye & M & Erik & KT230819 & KT827177 \\
\hline isPl29 & İstanbul/Türkiye & M & Erik & - & KT827114 \\
\hline isP132 & İstanbul/Türkiye & $\mathrm{M}$ & Erik & KT230756 & KT827116 \\
\hline is $\mathrm{P} 150$ & İstanbul/Türkiye & $\mathrm{M}$ & Erik & KT230761 & - \\
\hline isP154 & İstanbul/Türkiye & $\mathrm{M}$ & Erik & KT230765 & KT827124 \\
\hline isP160 & İstanbul/Türkiye & $\mathrm{M}$ & Erik & - & KT827126 \\
\hline isP192 & İstanbul/Türkiye & M & Erik & KT230779 & KT827136 \\
\hline isP198 & İstanbul/Türkiye & M & Erik & KT230784 & - \\
\hline KyYhPl2 & Kayseri/Türkiye & M & Erik & KM409958 & - \\
\hline KyYhPl3 & Kayseri/Türkiye & M & Erik & KM409965 & - \\
\hline KyYhP15 & İstanbul/Türkiye & M & Erik & KM409945 & - \\
\hline PS & Sırbistan ve Karadağ & M & P. sp. & AJ243957 & AJ243957 \\
\hline RS1 & Sirbistan ve Karadağ & M & Şeftali & EF626570 & - \\
\hline RS2 & Sirbistan ve Karadağ & $\mathrm{M}$ & Erik & EF626571 & - \\
\hline RS3 & Sırbistan ve Karadağ & $\mathrm{M}$ & Erik & EF626572 & - \\
\hline RS4 & Sirbistan ve Karadağ & $\mathrm{M}$ & Kayıs1 & EF626573 & - \\
\hline RS5 & Sirbistan ve Karadağ & M & Şeftali & EF626574 & - \\
\hline RS6 & Sırbistan ve Karadağ & $\mathrm{M}$ & Şeftali & EF626575 & - \\
\hline SK 68 & Macaristan & M & - & - & M92280 \\
\hline SK1 & Slovakya & $\mathrm{M}$ & Seftali & EF626576 & - \\
\hline SK2 & Slovakya & $\mathrm{M}$ & Şeftali & EF626577 & - \\
\hline VAR-2/531 & Slovakya & M & P. persica & HF585100 & HF585100 \\
\hline VAR-2/551 & Slovakya & M & P. persica & HF585101 & HF585101 \\
\hline VAR-2/B23 & Slovakya & M & P. persica & HF585104 & - \\
\hline VAR-2/M13 & Slovakya & $\mathrm{M}$ & P. armeniaca & HF585103 & - \\
\hline VAR-2/SE & Slovakya & $\mathrm{M}$ & P. domestica & HF585102 & - \\
\hline
\end{tabular}


Çizelge 2 (Devamı). Filogenetik analizlerde kullanılan GenBank izolatları

\begin{tabular}{|c|c|c|c|c|c|}
\hline \multirow[t]{2}{*}{ İzolat } & \multirow[t]{2}{*}{ Şehir/Ülke } & \multirow[t]{2}{*}{ Irk } & \multirow[t]{2}{*}{ Konukçu* } & \multicolumn{2}{|c|}{ GenBank No } \\
\hline & & & & P3-6K1 & CP+3'UTR \\
\hline BOR-3 & Slovakya & Rec & P. armeniaca & JQ794501 & AY028309 \\
\hline BULG & Bulgaristan & $\operatorname{Rec}$ & $\begin{array}{l}\text { P. domestica } \\
\text { (plum) }\end{array}$ & GU461889 & GU461889 \\
\hline $\mathrm{Cdn} 08$ & Kanada & $\operatorname{Rec}$ & $\begin{array}{c}\text { Plum rootstock } \\
\text { cultivar }\end{array}$ & HG964685 & HG964685 \\
\hline $\operatorname{Cdn} 10$ & Kanada & $\operatorname{Rec}$ & $\begin{array}{c}\text { Plum rootstock } \\
\text { cultivar }\end{array}$ & HG964686 & - \\
\hline IsHkPc218 & İstanbul/Türkiye & $\operatorname{Rec}$ & Şeftali & KM409970 & - \\
\hline $\mathrm{J} 4 \mathrm{c}$ & Polonya & $\operatorname{Rec}$ & P. domestica & EU117116 & EU117116 \\
\hline Kisl-1pl & Rusya & $\operatorname{Rec}$ & P. domestica & - & KM273015 \\
\hline KRN-1 & Slovakya & $\operatorname{Rec}$ & P. domestica & AF450314 & - \\
\hline MYV-1 & Slovakya & Rec & P. domestica & AF450315 & - \\
\hline o6 & Sirbistan & Rec & P. persica (peach) & GU474956 & GU474956 \\
\hline $\operatorname{Rec}(\mathrm{K} 18)$ & Ukrayna & Rec & P. cerasifera & - & KF472134 \\
\hline SK-514 & Slovakya & $\operatorname{Rec}$ & P. armeniaca & - & LN614587 \\
\hline Valjevka & Hirvatistan & $\operatorname{Rec}$ & P. domestica & JX013532 & JX013532 \\
\hline AbTk & Türkiye & $\mathrm{T}$ & P. armeniaca & - & EU734794 \\
\hline Ap39 & Türkiye & $\mathrm{T}$ & Kayısı & EU734797 & - \\
\hline is Ap70 & İstanbul/Türkiye & $\mathrm{T}$ & Kayıs1 & KT230771 & - \\
\hline isAp85 & İstanbul/Türkiye & $\mathrm{T}$ & Kay1s1 & KT230775 & - \\
\hline isAp87 & İstanbul/Türkiye & $\mathrm{T}$ & Kay1s1 & KT230776 & KT827134 \\
\hline is Ap 88 & İstanbul/Türkiye & $\mathrm{T}$ & Kay1s1 & KT230777 & - \\
\hline isAp89 & İstanbul/Türkiye & $\mathrm{T}$ & Kay1s1 & KT230778 & KT827135 \\
\hline isAp93 & İstanbul/Türkiye & $\mathrm{T}$ & Kay1s1 & KT230780 & KT827137 \\
\hline isPc75 & İstanbul/Türkiye & $\mathrm{T}$ & Şeftali & KT230772 & KT827131 \\
\hline isPl117 & İstanbul/Türkiye & $\mathrm{T}$ & Erik & KT230788 & KT827146 \\
\hline isPl121 & İstanbul/Türkiye & $\mathrm{T}$ & Erik & KT230789 & - \\
\hline isPl122 & İstanbul/Türkiye & $\mathrm{T}$ & Erik & KT230790 & - \\
\hline isPl123 & İstanbul/Türkiye & $\mathrm{T}$ & Erik & KT230791 & KT827147 \\
\hline isP165 & İstanbul/Türkiye & $\mathrm{T}$ & Erik & KT230769 & KT827129 \\
\hline isP166 & İstanbul/Türkiye & $\mathrm{T}$ & Erik & KT230770 & KT827130 \\
\hline isP176 & İstanbul/Türkiye & $\mathrm{T}$ & Erik & KT230773 & - \\
\hline $\mathrm{P} 145$ & Türkiye & $\mathrm{T}$ & Erik & EU734802 & - \\
\hline LV-141pl & Letonya & $\mathrm{W}$ & Erik & - & HQ670746 \\
\hline LV-145bt & Letonya & $\mathrm{W}$ & Erik & HQ670748 & HQ670748 \\
\hline UKR44189 & Ukrayna & $\mathrm{W}$ & P. spinosa & N596110 & N596110 \\
\hline W3174 & Kanada & W & P. domestica & AY912055 & AY912055 \\
\hline Winona & Rusya & $\mathrm{W}$ & P. domestica & - & KC347608 \\
\hline
\end{tabular}

*Konukçu ismi GenBank'da belirtildiği gibi verilmiştir.

\section{Bulgular ve Tartışma}

Bursa ili ve civarında kapama bahçelerde PPV enfeksiyonu incelenmiş, 50 ticari bahçeden 102 'ü şeftali ve 16 erik olmak üzere 118 örnek toplanmıştır. Bursa'da beklendiği gibi şeftali bahçelerinin yoğun olduğu görülmüştür. Survey güzergâhında diğer sert çekirdekli meyve türlerinden sadece erik türünde kapama bahçelere rastlanmış, kapama badem, kayısı, kiraz ve vişne bahçesi görülmemiştir. PPV belirtisi taşıyan yapraklar üzerinde lekeler, damar boyu renk açılmaları, renkli halkalar olarak gözlenmiştir. Örnek toplama Mayıs ayında gerçekleştirildiğinden olgunlaşmış meyvelerde belirti gözleme imkânı olmamıştır. 118 örnek DASI-ELISA ve RT-PCR yöntemi ile test edilmiştir. Her örnek DASI-ELISA ile iki kez test edilmiş ortalama değerler alınmıştır. Ortalama OD değerleri 0.07 ile 2.835 arasında değişmiştir. Pozitif örneklerin OD değerinin 0.532 üzerinde olduğu gözlenmiştir. Survey çalışmasında PPV belirtisi gösteren 55 örnek ve belirti göstermeyen 9 örnek olmak üzere toplamda 64 (\% 54) örnek serolojik yöntem sonucunda da pozitif çıkmıştır. 50 kapama bahçenin 32 (\%64)'sinde pozitif örnek tespit edilmiştir. 118 örneğin tamamı için cDNA elde edilmiş ve daha sonra bu cDNA örnekleri iki primer çifti ile çoğaltılmıştır. Serolojik yöntem ile pozitif bulunan 64 örneğin tamamı için iki amplikon bölgesinden en az biri başarılı olarak çoğaltılmış ve PPV varlı̆ğ moleküler yöntem ile de desteklenmiştir.

RT-PCR ile çoğaltılan amplikonlar dizilenmiş, toplamda 55 örneğin P3-6K1 bölgesi, 61 örneğin CP3'UTR bölgesi temiz olarak dizilenmiştir. 55 adet P36K1 bölgesi için ilk sekans ürünlerinin $5^{\prime}$ ve 3 ' bölgesindeki belirsiz nükleotidleri içeren uç kısımları temizlendikten sonra 664 nt uzunluğunda temiz diziler elde edilmiştir. Dizisi elde edilen 644nt'lik bölgenin 551 bazlık kısmı P3 geninin 3' bölgesini içerirken, 153 bazlık kısmi ise 6K1 geninin 5' bölgesine denk 
gelmektedir. Altmış bir adet ham CP-3'UTR bölgesi dizileri temizlendikten sonra 786 nt kısmı k1lif geni, ve 183 nt ise 3' UTR olmak üzere güvenilir 969 nt uzunluğunda parça elde edilmiştir. Temiz nükleotidler GenBank'a kaydedilmiş ve kayıt numaraları Çizelge 1 'de verilmiştir. Erik bahçelerine survey güzergâhında fazla rastlanılmamış şeftali bahçelerinin ise çok yaygın olduğu gözlenmiştir. $\mathrm{Bu}$ nedenle daha fazla şeftali ağacı incelenmiştir.

İç Anadolu Ankara ve Kayseri şehir merkezlerinin PPV ile yoğun bulaşık olduğu bilinmektedir. Elibüyük (2004) Ankara il merkezinde yürüttüğü çalışmada 935 örneği taramış, 523'ünün (286 kayısı, 172 erik, 65 şeftali) PPV ile bulaşık olduğunu rapor etmiştir. Örneklerin \% 88'inde (\%71 kayıs1, \% 60 erik ve \% 48 şeftali) hastalık simptomları gözlemlenmiștir. Araștırıcı diğer bir çalışmasında Ankara'daki değişik semtlerden 129 şeftali ağacindan toplanan örneklerden 59'unun (\% 45) bulaşık olduğunu rapor etmiştir (Elibüyük 2006). Kayseri il merkezinde kayısı örneklerinin $\% 89$ oranında PPV ile enfekteli olduğu belirlenmiştir (Ceylan ve ark., 2014). Ankara ve Kayseri'ye ilaveten, Aksaray'ın Ortaköy ilçesi ve civarı köyleri, Konya şehir merkezinin ve İstanbul şehir merkezinin PPV ile oldukça bulaşık olduğu rapor edilmiștir (Gürcan ve Ceylan, 2016b, Gürcan ve ark., 2016). Yapilan bu çalışma ile Bursa ili ve civarından ekonomik olarak yoğun şeftali yetiştiriciliğ̆in yapıldığı bahçelerden alınan örneklerin \% 64 oranında PPV-pozitif olduğu tespit edilmiştir. Bu değerler Bursa ilinin Ankara, Kayseri, Konya ve Aksaray/Ortahisar bölgesi gibi PPV ile yoğun bulaşık olduğunu göstermektedir.

Irk belirleme ve genetik varyasyon çalışmaları için her PPV ırkına ait GenBank örnekleri indirilmiș, Bursa örnekleri ile analiz edilmiş ve filogenetik ağaç oluşturulmuştur. Tüm izolatlar ırklarına göre beklendiği gibi gruplanmıştır. Her iki bölgenin filogenetik ağacında da Bursa izolatları Avrupa PPV-M ve Türkiye PPV-D ırkları ile gruplanmıştır. P3-6K1 bölgesinde 43 Bursa izolatı, Avrupa GenBank M izolatları ve daha önceki çalışmalarda Türkiye meyve bahçelerinden toplanan $\mathrm{M}$ izolatları ile gruplaşmıştır (Şekil 2). 8 izolat ise GenBank ve Türkiye PPV-D kayıtları ile grup oluşturmuş̧ur. CP+3'UTR bölgesinde ise Bursa'nın 40 izolatı (Bursa mı) Avrupa M izolatları ve Türkiye'de yayılan PPV-M izolatları ile gruplaşırken, aynı şekilde Bursa'nın 8 izolatı (Bursa mı) GenBank' ta kayıtlı PPVD izolatları ve Türkiye D izolatları ile grup oluşturmuştur (Şekil 3). Sonuç itibariyle şeftali ağaçlarından toplanan örneklerin dizi benzerlik ve filogenetik analiz sonucunda Avrupa $M$ irkından oldukları belirlenmiștir. Türkiye'deki erik, kayısı ve şeftali bahçelerindeki izolatlar ile Bursa izolatlarının filogenetik karşılaştırması, aralarındaki ilişkiyi belirlemek açısından önemli olmuştur. 2013 y1lında rapor edilen bir çalışmada dört ilin (Çanakkale, Hatay, Isparta illerinde şeftali ve Kayseri ili Yahyalı ilçesi erik) ticari bahçelerinde belirlenen PPV izolatlarının Avrupa M rrkı olduğu ve bahçe sahiplerinin fidan kaynağ olarak Bursa ilini işaret ettikleri belirtilmiş̧ir (Ceylan ve ark., 2013). Daha sonra yapılan bir çalışmada Aydın, Denizli, Isparta illeri meyve bahçeleri örneklerinin de Avrupa PPV-M 1rk1 oldukları belirlenmiştir (Gürcan ve Ceylan, 2016b). Bu çalışmalarda üretilen P3-6K1 gen bölgesi dizileri Bursa örnekleri ile birlikte analiz edildiğinde, Bursa M izolatlarının, Türkiye'de ekonomik bahçelerde bulunan izolatlarla genetik olarak yakın olduğu ve filogenetik ağaçta $M \quad$ rkk grubu altında gruplandıkları görülmektedir. Filogenetik analiz Bursa izolatları ile ülkenin geri kalan meyve bahçelerinden alınan izolatlar arasındaki yakın ilişkiyi göstermektir. PPV-M' nin ilk olarak Yunanistan'da şeftaliden izole edildiği ve şeftali ağaçlarında yaygın olduğu belirtilmiştir (Levy ve ark. 2000). Türkiye'de de PPV-M'nin genelde şeftali ve erik bahçelerinde bulunması bir tesadüften ziyade Avrupa PPV-M ırkının şeftali ve erik fidanları yoluyla Türkiye'de yayıldığını işaret etmektedir.

Bursa PPV izolatlarının dizileri GenBank' da kayıtlı PPVdizileri ile birlikte analiz edilmiş, yeni katılan Bursa örnekleri ile berabar her bir irk grubunda genetik varyason belirlenmiştir. Toplamda 144 izolatın CP3'UTR bölgesi analiz edilmiş ve toplam genetik varyasyon \% 7,1 bulunmuştur. GenBank'da kayıtlı P36K1 bölgesi daha fazla olduğu için bu bölgenin genetik varyasyon analizinde toplamda 219 izolat kullanılmış ve toplam genetik varyasyon $\% 8,8$ bulunmuştur (Çizelge 3). 8 adeti bu çalışmada elde edilmek üzere toplamda 15 önekten oluşan Türkiye D grubu, CP3'UTR bölgesinde \% 1,6 varyasyon göstermiştir. Yine D ırkında, 8 adeti yine bu çalışmada elde edilen toplamda 45 adet $\mathrm{P} 3-6 \mathrm{~K} 1$ bölgesinde \% 1,7 varyasyon belirlenmiştir. Türkiye'den katılan bu yeni örneklerle D 1rkı grubu, PPV-W ve C'den sonra en yüksek genetik varyasyon gösteren grup olmuştur. Dünyada $\mathrm{D}$ grubu izolatları birçok ülkeden toplanmasına rağmen oldukça düşük varyasyon göstermiştir. Diğer taraftan Türkiye'ye has olan PPV-M İstanbul (15 örnek) her iki genomik bölge için Türkiye örneklerinin de içinde bulunduğu PPV-M (P3-6K1 bölgesi için 58 örnek ve CP-3'UTR bölgesi için 108 örnek) grubundan daha düşük varyasyon göstermiş̧ir. Bu çalışmada elde edilen ve GenBank örnekleri birlikte analiz edildiğinde, PPV$\mathrm{M}$ gurubu örnek sayısı en fazla olan grup olmasina rağmen genetik varyasyon $\mathrm{P} 3-6 \mathrm{~K} 1$ bölgesi için \% 1,3 ve CP-3'UTR bölgesi için \% 1,4 olarak hesaplanmıştır.

Bursa'dan elde edilen örnekler ve GenBank kayıtları birlikte analiz edilerek her iki bölge için rrk gruplar arası benzerlik ve 1raksaklık (divergence) değerleri belirlenmiştir. 


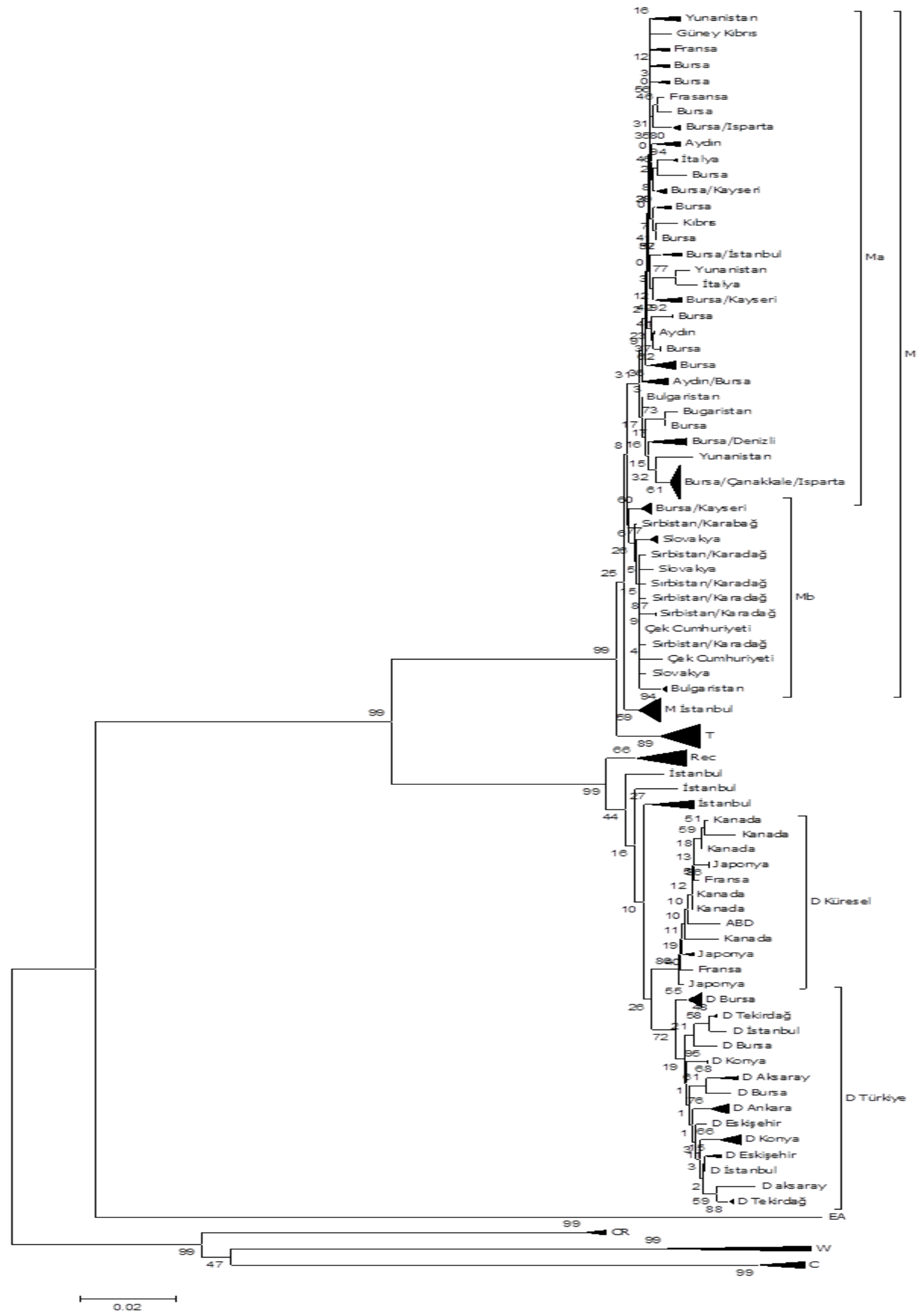

Şekil 2. Bursa ve GenBank izolatlarının P3-6K1 bölgesi NJ filogenetik analiz görüntüleri 


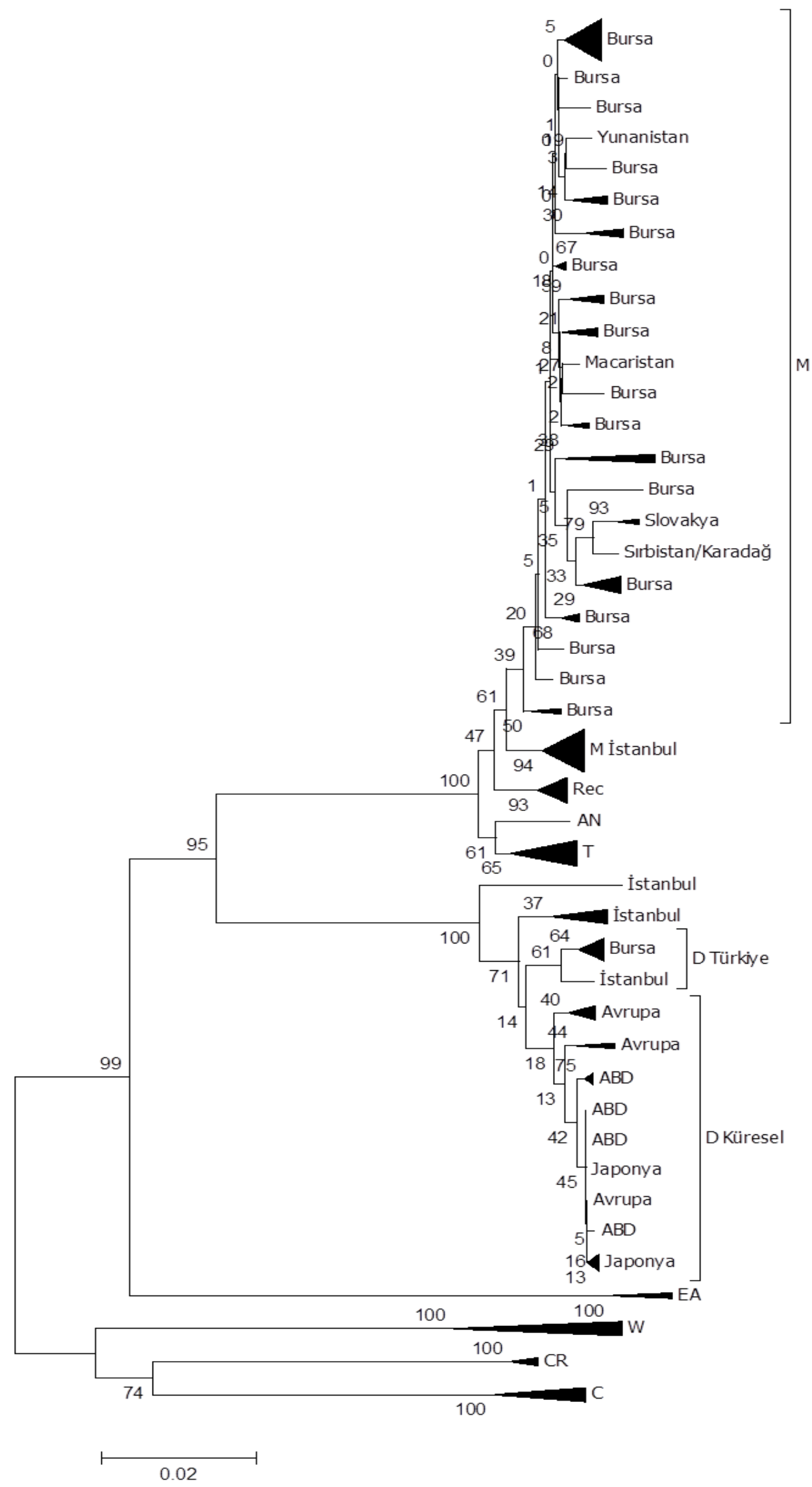

Şekil 3. Bursa ve GenBank izolatlarının CP-3'UTR bölgesi NJ filogenetik analiz görüntüleri 
P3-6K1 bölgesi için PPV ırk gruplar arası benzerlik ve rraksaklık (divergence) değerleri Çizelge 4'de ve CP3'UTR bölgesi için ise Çizelge 5'de verilmiştir. İstanbul dışında Türkiye M izolatları GenBank M izolatları ile tek grup oluşturduğundan benzerlik ve rraksaklık hesaplamalarında İstanbul $\mathrm{M}$ izolatları ve tüm $\mathrm{M}$ izolatları iki ayrı grup olarak alınmıştır. Türkiye D izolatları ise filogenetik ağaçta küresel D izolatlarından farklı bir grup oluşturduğundan her iki grubun benzerlik ve rraksaklık değerini görmek amacıyla ayrı gruplar olarak değerlendirilmiştir. Böylece İstanbul $M$ ve Türkiye D gruplarının GenBank M ve D örnekleriyle kıyaslama imkanı sağlanmıștır. Türkiye D izolatları, küresel D izolatları ile P3-6K1 bölgesinde \% 97.8 ve CP-3'UTR bölgesinde ise \% 98.2 benzerlik göstermektedir. İstanbul $\mathrm{M}$ izolatları, Avrupa $\mathrm{M}$ izolatı grubu ile P3-6K1 bölgesinde \% 98 ve CP-3'UTR bölgesinde 97.7 benzerlik göstermektedir. Türkiye D izolatları ile küresel D izolatlarının PPV-T ırkına benzerlikleri çok yakın bulunmuştur. Türkiye D izolatları, PPV-T ile CP-3'UTR bölgesinde \% 90.2 benzerlik gösterirken küresel D izolatları aynı bölge içinPPV-T ile \%90,4 benzerlik göstermiştir. P3-6K1 bölgesinde ise aynı değerler yine çok yakın olup sırası ile $\% 86.4$ ve $\% 86.7$ 'dir.

Bursa'nın Şehitler yerleşim yerinden 2 erik bahçesinden toplanan 8 örneğin PPV-D rkk ile bulaşık olduğu görülmüştür. PPV-D dünyada en yaygın olan ırktır
(García ve Cambra, 2007). PPV' nin tespit edildiği hemen her ülkede PPV-D ırkı rapor edilmiştir (James ve ark., 2013). Ancak, PPV-D ırkı ilginç bir şekilde dünya da en yaygın ırk olmasına rağmen diğer ırklara nazaran düşük genetik varyasyon göstermektedir (James ve ark., 2013). Fakat Türkiye'de yapılan PPV-D çalışmaları bu ırkın diğer ülkelerden farklı olduğunu ve Türkiye'de PPV-D varyasyonunun dünya toplamından daha yüksek olduğunu göstermektedir (Gürcan ve Ceylan, 2016b). PPV-D ilk olarak serolojik testler sonucunda Ankara'da rapor edilmiştir (Elibüyük, 2004). Sonrasında moleküler testler ile PPV-D Ankara yanı sıra Aksaray, Bursa, Eskişehir, İstanbul, Konya ve Tekirdağ'da tespit edilmiştir (Gürcan ve Ceylan, 2016b). Bu izolatların birçoğunun P3-6K1 gen bölgesi dizilenmiş, aynı zamanda D izolatlarından 6 adetinin tüm genom dizi analizi yapılmış, Türkiye PPV-D izolatlarının filogenetik ağaçta bir grup, dünyanın geri kalan ülkelerinin ise ayrı bir grup oluşturduğu görülmüştür (Gürcan ve Ceylan, 2016a). Bu çalışmada yapılan iki filogenetik analizde de Bursa D izolatları Türkiye D izolatlarının yanında konumlanmıştır. Türkiye D grubunun en dış kısmında İstanbul D izolatları yer almıştır. Bursa D izolatları da eklendiğinde de sonuç değişmemiş, Türkiye D izolatları üzerine yapılan önceki filogenetik çalışmalarda olduğu gibi (Gürcan ve Ceylan, 2016ab) Türkiye D izolatları küresel D gurubundan genetik olarak farklı çıkmıştır.

Çizelge 3.PPV izolat gruplarında grup içi evrimsel ıraksaklık değerleri

\begin{tabular}{|c|c|c|c|c|c|}
\hline \multirow[b]{2}{*}{ Irk } & \multicolumn{2}{|c|}{ K1l1f + 3'UTR } & \multirow[b]{2}{*}{ Irk1 } & \multicolumn{2}{|c|}{ PP3-6K1 } \\
\hline & $\begin{array}{l}\text { İzolat } \\
\text { Sayısı }\end{array}$ & $\begin{array}{c}\text { Genetik } \\
\text { Diversity }\end{array}$ & & $\begin{array}{l}\text { İzolat } \\
\text { Sayis1 }\end{array}$ & $\begin{array}{c}\text { Genetik } \\
\text { Diversity }\end{array}$ \\
\hline PPV-An & 1 & $\mathrm{n} / \mathrm{c}$ & PPV-CR & 3 & 0.006 \\
\hline PPV-D Küresel & 22 & 0.006 & PPV-D Küresel & 15 & 0.007 \\
\hline PPV-CR & 3 & 0.007 & PPV-M İstanbul & 15 & 0.009 \\
\hline PPV-Rec & 9 & 0.009 & PPV-T & 15 & 0.012 \\
\hline PPV-M İstanbul & 15 & 0.010 & PPV-M** & 108 & 0.014 \\
\hline PPV-T & 9 & 0.011 & PPV-C & 4 & 0.014 \\
\hline PPV-M* & 58 & 0.013 & PPV-Rec & 10 & 0.016 \\
\hline PPV-EA & 2 & 0.015 & PPV-D Türkiye & 45 & 0.017 \\
\hline PPV-D Türkiye & 15 & 0.016 & PPV-W & 3 & 0.040 \\
\hline PPV-C & 5 & 0.022 & PPV-EA & 1 & $\mathrm{n} / \mathrm{c}$ \\
\hline PPV-W & 5 & 0.040 & & & \\
\hline Toplam & 144 & 0.071 & Toplam & 219 & 0.088 \\
\hline
\end{tabular}

*5 GenBank örneği ve 53 Adet Bursa örneğini içermektedir

** 36 GenBank ve 72 adet Türkiye örneğini içermektedir

Türkiye'de iki M grubu bulunmaktadır. Biri Avrupa'dan fidancılık yoluyla Türkiye'ye yayıldığı varsayılan Avrupa PPV-M ırkıdır. Diğeri ise sadece İstanbul'da keşfedilmiş olan $\mathrm{M}$ ırkının bir alt grubu sayılan PPV-M İstanbul gurubudur. Bu gruptan 10 izolatın tüm genomu dizilenmiş ve Avrupa $\mathrm{M}$ grubundan genetik olarak farklı olduğu rapor edilmiştir (Teber ve Gürcan, 2016). PPV-M İstanbul grubunun kökenine dair bir hipotez geliştirilmemiştir. Avrupa
PPV-M ırkı ise, Güney, Doğu ve Orta Avrupa'da (Myrta ve ark. 2001) oldukça yaygındır. Serolojik ve moleküler veriler Avrupa'da iki PPV-M alt grubunun (PPV-Ma ve PPV-Mb) var olabileceğini işaret etmektedir (Myrta ve ark., 2001, Dallot ve ark., 2011). García ve ark., (2014) PPV-M'nin güvenilir dizi analizleri ile Avrupa dışında tespit edilmediğini belirtmişlerdir. Aslında serolojik tanımlama ile PPV-M'nin Türkiye'de özellikle de Ankara'da mevcut olduğu rapor edilmiştir (Elibüyük, 
2004). Fakat bu çalışmalarda PPV-M'ye özgün antikorlar kullanılmıştır. PPV-M ve PPV-D rekombinantı olan PPV-T'nin PPV-M'ye özgün antikorlara reaksiyon gösterdiği bilinmektedir. Gerçekten de güvenilir nükleotid dizilme yöntemi ile yapılan bir çalışmada Ankara şehir merkezinin farklı semtlerinde tesadüfü olarak alınan 122 örnek toplanmış ve P3-6K1 gen bölgesi dizilenmiş 115 örneğin PPV-T ve 7 örneğin PPV-D olduğu görülmüştür. Çalışma Ankara şehir merkezindeki ağaçlarda PPV-M ırkının değil PPV-T ırkının olduğunu göstermiştir (Gürcan ve Ceylan, 2016b). Türkiye dışında sadece Arnavutluk'ta rapor edilen (Palmisano ve ark. 2015) PPV-T 1rk1 Türkiye'de Ankara, İzmir, İstanbul, Kayseri, Konya, Tekirdağ ve Samsun illerinde tespit edilmiştir (Ulubaş Serçe ve ark. 2009; Ulubaş Serçe ve ark. 2011; İlbağ ve
Çıtır, 2014; Deligöz ve ark. 2015, Gürcan ve ark 2013b, Gürcan and Ceylan 2016b). Türkiye $T$ izolatının ilk genom dizilemesi Ulbaş Serçe ve ark. (2009) tarafından yapılmış, daha sonra 14 adetinin tüm genomu dizilenmiş, farklı filogenetik gurupların olduğu görülmüştür (Ceylan ve ark, 2015. Sonuç itibariyle bu çalışmada Bursa'da PPV-T ırkının belirlenmemiş olması, Türkiye'de ekonomik meyve bahçelerinde PPV$M$ ırkı olduğu yaklaşımını desteklemiştir. Daha önceki araştırmamızda, Bursa'da bir adet izolatın PPV-Rec olduğu rapor edilmiş (Gürcan ve Ceylan, 2016b) ise de PPV-Rec izolatının belirlendiği bölgeye tekrar rastlanmamış, örneklerde PPV-Rec irkı saptanmamıştır. Bu da Bursa ilinde PPV-Rec ırkının muhtemelen yaygın olmadığına, yeni giriş yaptığına işaret etmiştir.

Çizelge 4. CP-3'UTR bölgesi gruplar arası evrimsel benzerlik ve ıraksaklık değerleri

\begin{tabular}{lccccccccccc} 
& D-Tr & D Kr & M-İst & \multicolumn{1}{c}{ M } & \multicolumn{1}{c}{ T } & \multicolumn{1}{c}{ CR } & \multicolumn{1}{c}{ W } & \multicolumn{1}{c}{ C } & \multicolumn{1}{c}{ Rec } & An & EA \\
\hline D-Tr & & 0.982 & 0.896 & 0.9 & 0.902 & 0.855 & 0.852 & 0.852 & 0.898 & 0.901 & 0.867 \\
D-Kr & 0.018 & & 0.897 & 0.902 & 0.904 & 0.854 & 0.85 & 0.853 & 0.9 & 0.904 & 0.867 \\
M-İst & 0.104 & 0.103 & & 0.977 & 0.976 & 0.856 & 0.843 & 0.85 & 0.977 & 0.975 & 0.866 \\
M & 0.100 & 0.098 & 0.023 & & 0.971 & 0.858 & 0.843 & 0.85 & 0.975 & 0.972 & 0.869 \\
T & 0.098 & 0.096 & 0.024 & 0.029 & & 0.86 & 0.845 & 0.847 & 0.977 & 0.98 & 0.872 \\
CR & 0.145 & 0.146 & 0.144 & 0.142 & 0.140 & & 0.873 & 0.893 & 0.859 & 0.866 & 0.848 \\
W & 0.148 & 0.150 & 0.157 & 0.157 & 0.155 & 0.127 & & 0.868 & 0.845 & 0.854 & 0.845 \\
C & 0.148 & 0.147 & 0.150 & 0.150 & 0.153 & 0.107 & 0.132 & & 0.85 & 0.854 & 0.818 \\
Rec & 0.102 & 0.100 & 0.023 & 0.025 & 0.023 & 0.141 & 0.155 & 0.150 & & 0.978 & 0.875 \\
An & 0.099 & 0.096 & 0.025 & 0.028 & 0.020 & 0.134 & 0.146 & 0.146 & 0.022 & & 0.874 \\
EA & 0.133 & 0.133 & 0.134 & 0.131 & 0.128 & 0.152 & 0.155 & 0.182 & 0.125 & 0.126 & \\
\hline
\end{tabular}

Tr: Türkiye, Kr: Küresel, İst: İstanbul

Çizelge 5. P3-3'UTR bölgesi gruplar arası evrimsel benzerlik ve ıraksaklık değerleri

\begin{tabular}{lcccccccccc}
\hline & D-Tr & D-Kr & \multicolumn{1}{c}{ M-İst } & \multicolumn{1}{c}{ M } & T & CR & W & C & Rec & EA \\
\hline D-Tr & & 0.978 & 0.871 & 0.874 & 0.864 & 0.739 & 0.7 & 0.707 & 0.968 & 0.714 \\
D-Kr & 0.022 & & 0.875 & 0.876 & 0.867 & 0.726 & 0.7 & 0.701 & 0.974 & 0.731 \\
M-İst & 0.129 & 0.125 & & 0.98 & 0.973 & 0.739 & 0.691 & 0.691 & 0.875 & 0.727 \\
M & 0.126 & 0.124 & 0.020 & & 0.971 & 0.739 & 0.69 & 0.691 & 0.876 & 0.729 \\
T & 0.136 & 0.133 & 0.027 & 0.029 & & 0.727 & 0.691 & 0.681 & 0.872 & 0.72 \\
CR & 0.261 & 0.274 & 0.261 & 0.261 & 0.273 & & 0.796 & 0.781 & 0.721 & 0.685 \\
W & 0.300 & 0.300 & 0.309 & 0.310 & 0.309 & 0.204 & & 0.757 & 0.691 & 0.689 \\
C & 0.293 & 0.299 & 0.309 & 0.309 & 0.319 & 0.219 & 0.243 & & 0.696 & 0.677 \\
Rec & 0.032 & 0.026 & 0.125 & 0.124 & 0.128 & 0.279 & 0.309 & 0.304 & & 0.731 \\
EA & 0.286 & 0.269 & 0.273 & 0.271 & 0.280 & 0.315 & 0.311 & 0.323 & 0.269 & \\
\hline
\end{tabular}

Tr: Türkiye, Kr: Küresel, İst: İstanbul

\section{Sonuç}

Sonuç itibariyle, bu çalışmada Bursa'da ekonomik olarak yetiştiriciliğin yapıldığı şeftali ve erik bahçelerinde surveyler yapılmış, DASI-ELISA ve RTPCR yöntemleri ile örnekler test edilmiş, PPV-pozitif alanlar belirlenmiş ve nükleotid dizileme çalışmaları ile virüs ırkları ve genetik varyasyonu çalışılmıştır. Yapılan çalışma ile birkaç önemli sonuç ortaya konmuştur. Bunlardan biri Bursa ilindeki enfeksiyon seviyesinin önceki çalışmalara göre daha ayrıntılı olarak ortaya konmasıdır. İkinci olarak Türkiye'de daha önceki çalışmalarda PPV ile bulaşı olduğu rapor edilen ticari bahçe izolatları ile Türkiye'nin önemli fidan üretim merkezi olan Bursa ili izolatlarının ilişkisi belirlenmiş̧ir. Ayrıca Türkiye'de PPV ırk 
epidemiyolojisi ve zengin genetik varyasyonu destekleyen sonuçlar elde edilmiştir. Bursa ili Türkiye'de önemli bir şeftali üreticisi bölge olmasının yanısıra oldukça önemli bir fidan üretim merkezidir. Fidancılığa uygun iklim koşulları ve görece gelişmiş tarımsal ticaret potansiyeli bu bölgede hem fidan üretimini arttırmış hem de Avrupa'dan gelen fidanların Türkiye içinde dağıtım merkezi olmasını sağlamıştır. Bursa ili fidan trafiğinde ve dolayısıyla fidan ile hastalıkların ülke içerisinde taşınmasında önemli bir konumda bulunmaktadır.

\section{Kaynaklar}

Akbaş, B., Değirmenci, K., Çiftçi, O., Kaya, A., Yurtmen, M., Uzunoğulları, N., Çelik, N., Türkölmez, Ş., 2011. Update on Plum pox virus distribution in Turkey. Phytopathology Mediterrian, 50: 75-83.

Cambra, M., Capote, N., Myrta, A,. Llácer, G., 2006. Plum pox virus and the estimated costs associated with sharka disease. EPPO Bull. 36: 202-204.

Candresse, T., Svanella-Dumas, L., Gentit, P., Çağlayan, K., Çevik, B., 2007. First report of the presence of Plum pox virus Rec strain in Turkey. Plant Dis. 91: 331.

Ceylan, A., Gürcan, K., Akbulut, M., 2015. Complete nucleotide sequence analysis of Plum Pox Virus 'Turkey' isolates. International Conference on Virus and Other Graft Transmissible Disease of Fruit Crops, S.50, 8-12 Haziran, Morioka, Japonya.

Ceylan, A., Gürcan, K., Akbulut, M., Ghaderi, M., 2014. Kayseri'de yüksek şarka enfeksiyonu. Erciyes Üniversitesi Fen Bilimleri Enstitüsü Dergisi, 30(2): 80-85.

Ceylan, A., Gürcan, K., Ghaderi, M., Akbulut, M., Ulubaş Serçe, Ç., 2013. Transmission route of new plum pox virüs in Turkey. 2nd International Symposium on Plum Pox Virus, S.19, 3-6 September, Olomouc, Czech Republic.

Crescenzi, A., D'aquino, L., Comes, S., Nuzzaci, M., Piazzolla, P., 1997. Charecterisation of the sweet cherry isolate of Plum pox potyvirus, Plant Dis. 81(7): 711-714.

Çelik, N., Topkaya Kütük, B., 2013. Antalya ilinde şarka virüs hastalığının belirlenmesi. Derim, 30(2):1-10.

Çıtır, A., İlbağı, H., 2008. Serological identification of some important viruses on fruit trees and bushes in Tekirdağ province of Turkey, Proceedings of the Twentieth International Symposium on Virus and Virus-like Diseases of Temperate Fruit Crops, Fruit Tree Diseases", Antalya, Turkey. Acta Hortic. 781: 103-106.

Dallot, S., Glasa, M., Jevremovic, D., Kamenova, I., Paunovic, S., Labonne, G., 2011. Mediterranean and central-eastern European countries host viruses of two different clades of Plum pox virus strain M. Arch. Vir. 156: 539-542.

Deligöz, İ., Değirmenci, K., Sökmen, M., 2015. Samsun İlinde Sert Çekirdekli Meyve Türlerinde Şarka Hastalığı Etmeninin (Plum pox virus) Belirlenmesi. Anadolu Tarım Bilimleri Dergisi, 30(3):227-235.

Elibüyük, I.Ö. 2004. Current situation of sharka disease in Ankara, Turkey. Phytoparasitica, 32(4): 417420.

Elibüyük, İ.Ö. 2006. Detection of Plum Pox Virus in Ornamental Prunus Cerasifera. Phytoparasitica, 34 (4): 347-352.

EPPO, 2004. Standard PM 7/32 Plum pox potyvirus. Bulletin EPPO Bull. 34: 247-256.

García, J.A. Glasa M., Cambra, M., Candresse, T., 2014. Plum pox virus and sharka: a model potyvirus and a major disease. Molecular Plant Pathology, 15(3): 226-41.

García, J. A., Cambra, M., 2007. Plum pox virus and sharka disease. Plant Viruses, 1:69-79.

Glasa, M., Marie-Jeanne, V., Moury, B., Kúdela, O., Quiot, J.B., 2002. Molecular variability 17 of the P3-6K1 genomic region among geographically and biologically distinct 18 isolates of Plum pox virus. Arch Virol. 147:563-575.

Glasa, M., Malinowski T., Predajna L., Pupola N., Dekena D., Michalczuk, L., Candresse, T., 2011. Sequence variability, recombination analysis, and specific detection of the $\mathrm{W}$ strain of Plum pox virus. Phytopathology, 101(8): 980-985.

Glasa, M., Prikhodko, Y., Predajna, L., Nagyova, A., Shneyder, Y., Zhivaeva, T., Subr, Z., Cambra, M., Candresse, T., 2013. Characterization of sour cherry isolates of Plum pox virus from the Volga basin in Russia reveals a new cherry strain of the virus. Phytopathology, 103(9): 972-979.

Glasa, M., Palkovics, L., Komínek, P., Labonne, G., Pittnerová, S., Kúdela, O., Candresse, T., Subr, Z., 2004. Geographically and temporally distant natural recombinant isolates of Plum pox virus are genetically very similar and form a unique PPV. Journal of General Virology, 85: 2671-81.

Gümüs, M., Paylan, I.C., Matic, S., Myrta, A., Sipahioglu H.M., Erkan, S., 2007. Occurrence and distribution of stone fruit viruses and viroids in commercial plantings of Prunus species in western Anatolia, Turkey, Journal of Plant Pathology, 89: 265-268.

Gürcan, K., Ceylan, A., 2016a. Full Genome Analysis of Plum pox virus-D isolates of Turkey. 3nd International Symposium on Plum Pox Virus, S. 19, 9-13 Mayıs, Antalya, Türkiye.

Gürcan, K., Ceylan, A., 2016b. Strain identification and sequence variability of plum pox virus in Turkey. Turkish Journal of Agriculture and Forestry. DOI: 10.3906/tar-1509-97.

Gürcan, K., Teber, S., Değirmenci, K., 2016. High Sequence variability of Plum pox virus: A new divergent group of Marcus strain. Romanian 
Biotechnological Letters (kabul edildi).

İlbağı, H., , Çıtır, A., 2014. Detection and partial molecular characterization of Plum pox virus on almond trees in Turkey. Phytoparasitica, 42(4): 485-491.

İlbağı, H., Citır, A., Bostan, H., 2008. Prunus spinosa L. A natural wild host of some important fruit viruses in Tekirdağ, Turkey, Proceedings of the Twentieth International Symposium on Virus and Virus-like Diseases of Temperate Fruit Crops, Fruit Tree Diseases, Antalya, Turkey, Acta Hortic., 781, 33-36.

James, D., Varga, A., Thompson, D., Hayes, S., 2003. Detection of a new and unusual isolate of Plum pox plum (Prunus domestica virus in). Plant Dis. 87: 1119-1124.

James, D., Varga, A., Sanderson, D., 2013. Genetic diversity of Plum pox virus: strains, disease and related challenges for control. Can. J. Plant Pathol. 35: 431-441.

Kalashyan, Y.A., Bilkey, N.D., Verderevskaya, T.D., Rubina, E.V., 1994. Plum pox virus on sour cherry in Moldava. EPPO Bull. 24: 645-649.

Kerlan, C., Dunez, J., 1979. Différenciation biologique et sérologique des souches du virus de la sharka. Annales de Phytopathologie, 11:241-250.

Koç, G., Baloğlu, S. 2006. First report of sharka in the Çukurova region of Turkey. J. of Plant Pathol., 88 (3 suppl.): 68.

Levy, L., Damsteegt, V., Welliver, R., 2000. First report of Plum pox virus (sharka disease) in Prunus persicae in the United States. Plant Dis, 84: 202.

Kurçman, S., 1973. Detection of sharka virus on apricot and plum trees in Ankara. Journal fo Turk Pyhtopatholgy, 2:124-129.

Maejima, K., Himeno, M., Komatsu, K., Takinami, Y., Hashimoto, M., Takahashi, S., Yamaji, Y., Oshima, K. Namba, S., 2011. Molecular epidemiology of Plum pox virus in Japan. Phytopathology, 101(5): 567-574.

Myrta, A., Boscia, D., Potere, O., Kolber, M., Nemeth, M., Terlizzi, B., Cambra, M., Savino, V., 2001. Existence of two serological subclusters of Plum pox virus, strain M. Eur. J. Plant Pathol. 107: 845848.

Palmisano, F., Boscia, D., Minafra, A., Myrta, A., Candresse, T., 2012. An a typical albanian isolate of Plum pox virus could be the progenitor of the Marcusstrain..http://icvf.jki.bund.de/dokumente/up $\operatorname{load} / 74140$ icvf2012abstracts.pdf. Accessed 15 October 2014.

Palmisano, F., Minafra, A., Myrta, A. Boscia, D., 2015. First Report Of Plum Pox Virus Strain PPVT in Albania. J. Plant Pathol. 97(2): 391-403.

Roy, A.S., Smith, I.M., 1994. Plum pox situation in Europe. Bulletin OEPP/EPPO Bulletin. 24: 515523.

Sahtiyanc1, S., 1969. Virus de la Sharka chez la prunier. Bullet. Phytosan FAO, 69.

Scholthof, K.B., Adkins, S., Czosnek, H., Palukaitis, P., Jacquot, E., Hohn, T., Hohn, B., Saunders, K., Candresse, T., Ahlquist, P., Hemenway, C., Foster, G.D., 2011. Top 10 plant viruses in molecular plant pathology. Mol Plant P. 12: 938-954.

Kumar, S., 2013. MEGA6: Molecular 6 Evolutionary Genetics Analysis Version 6.0. Mol. Biol. Evol. 30:2725-2729.

Teber, S., Gürcan K., 2016. Recombination analysis of 51 PPV isolates including 10 genomes of PPV-M Istanbul, 3nd International Symposium on Plum Pox Virus, S. 33, 9-13, Antalya, Turkey.

Thompson, D., McCann, M., MacLeod, M., Lye, D., Green, M., James, D., 2001. First report of Plum Sertkaya, G., Ulubaş, Ç., Çă̆layan, K. 2003. Detection and characterization of Plum pox potyvirus (PPV) by DAS-ELISA and RTPCR/ RFLP analysis in Turkey, Turk. J. Agric. For., 27: 213-220.

Tamura, K., Nei, M., Kumar, S., 2004. Prospects for inferring very large phylogenies by 4 using the neighbor-joining method. PNAS 101:1103011035.

Tamura, K., Stecher, G., Peterson, D., Filipski, A., pox virus in Ontario, Canada. Plant Dis. 85 (11): 97.

Ulubaş Serçe, C., Candresse. T., Svanella-Dumas, L., Krizbai, L., Gazel, M., Çağlayan, K., 2009. Further characterization of a new recombinant group of Plum pox virus isolates, PPV-T, found in orchards in the Ankara province of Turkey. Virus Res. 142 (1-2):121-126.

Ulubaş Serçe Ç., Gazel, M., Çağlayan, K., 2011. Plum pox virus streynlerinin Türkiye' deki Dağılımı. Türkiye IV. Bitki Koruma Kongresi Bildirileri, Kahramanmaraş s. 72.

Wetzel T., Candresse T., Ravelonandro M., Delbos R.P., Mazyad H., Aboul-Ata A.E., Dunez, J., 1991. Nucleotide sequence of the $3^{\prime}$ terminal region of the RNA from a widely divergent strain (El Amar) of Plum pox potyvirus. J. Gen. Vir. 72: 1741-1746. 